\title{
PPM Olahan Buah Naga Di Desa Baron Kecamatan Baron Nganjuk
}

\author{
Sayekti Suindyah Dwiningwarni ${ }^{1}$, Erwan Aristyanto² ${ }^{2}$ Fatimah Riswati $^{3}$, Mas'adah $^{4}$ \\ ${ }^{123}$ Universitas Wijaya Putra Surabaya \\ ${ }^{4}$ STIE Ahmad Dahlan, Lamongan
}

Email: sayektisuindyah@uwp.ac.id, email: erwanaristyanto@uwp.ac.id, email: fatimahriswati@uwp.ac.id, email : masadah1977@gmail.com

\begin{abstract}
Abstrak
Mitra PkM ini adalah UKM "ENZI" ini didirikan sejak tahun 2012, yang didirikan oleh sekelompok anak muda, dan memproduksi stik, dan kripik. Permasalahan yang dihadapi MItra adalah volume penjualan masih minimal, produksi dilakukan pada masa panen, tdiak memiliki tenaga pemasaran, dan belum memiliki pembukuan keuangan usaha.

Tujuan dari kegiatan PPM ini adalah untuk membantu memberikan solusi kepada Mitra dalam memecahkan permasalahan yang dihadapi. Solusi yang ditawarkan dalam kegiatan ini adalah memberikan pelatihan dan pendampingan dalam membuat laporan keuangan, rekrutmen tenaga pemasaran dan melakukan kerjasama dengan SMK di bidang pemasaran. Metode yang digunakan adalah pelatihan, pendampingan dan evaluasi. Hasil dari kegiatan ini yaitu menghasilkan rancangan laporan keuangan, konsep pemasaran yang sesuai dengan sasaran serta peningkatan volume penjualan. Dampak dari program PKM ini bagi Mitra adalah Mitra memiliki pembukuan keuangan sederhana, Mitra mulai berpikir yang lebih strategis agar produksi stik buah naga tetap dapat dilakukan walaupun buah naga tidak musim
\end{abstract}

Kata Kunci : UKM, Buah Naga, Peningkatan Penjualan

\section{PENDAHULUAN}

Desa Baron merupakan salah satu desa yang terletak di Kecamatan Baron Kabupaten Nganjuk. Desa Baron berada berada pada titik koordinat, garis lintang (latitude): -7.604685 dan garis bujur (longitude): 112.0527915 , memiliki luas wilayah $2,62 \mathrm{~km}$. Jumlah penduduk sebanyak 4.961 jiwa, terdiri dari 2.443 jiwa berjenis kelamin lakilaki dan 2.518 jiwa berjenis kelamin perempuan (Anonim, 2019). Desa Baron terdiri dari 3 dusun, antara lain : Dusun Baron, Dusun Lobeser dan Dusun Padasan. Sebagian besar penduduk memiliki mata pencaharian bertani. Sektor pertanian, perikanan dan kehutanan selama ini memberikan sumbangan sumbangan nomor 3 (tiga) setelah perdagangan besar, eceran, reparasi mobil dan sepeda motor (nomor 2) dan industri pengolahan (nomor 1) terhadap Produk Domestik Regional Bruto (PDRB) atas dasar harga berlaku dibandingkan sektor lain, yaitu sebesar 13,69\% (triwulan III tahun 2017), 12,35\% (triwulan II tahun 2018) dan 12,51 \%(triwulan III tahun 2018) ((Anonim, 2018). Data sumbangan sektor pertanian, perikanan dan kehutanan ini didukung dengan kondisi wilayah Kabupaten Nganjuk yang masih dominan pada sektor pertanian inilah yang memberikan kesempatan kepada para petani untuk Sub Tema Ekonomi, Sosial, dan Budaya $\quad 984$ 
mengembangkan produk hasil pertaniannya. Salah satunya adalah usaha yang dilakukan oleh para petani buah naga di Kecamatan Baron Kabupaten Nganjuk. Secara administratif Kecamatan Baron merupakan salah satu wilayah yang terletak di kabupaten Nganjuk, yang memiliki batas wilayah sebagai berikut: sebelah Timur: Kecamatan Kertosono, sebelah Selatan-Barat: Kecamatan Tanjung Anom dan sebelah Utara: Kecamatan Lengkong (Anonim, 2019).

Sebagian besar masyarakat Kecamatan Baron bekerja sebagai petani dan peternak, baik sebagai pemilik dan penggarap. Salah satu kegiatan komunitas masyarakat adalah petani buah naga. Buah naga (Dragon Fruits), buahnya yang berair, manis sedikit asam serta menyegarkan. Buah naga ini sangat cocok untuk dikembangkan menjadi produk olahan untuk meningkatkan kualitas hasil pertanian dan pendapatan petani. Di Kecamatan Baron ini hanya ada satu komunitas pembuat stik buah naga. Komunitas pembuat stik buah naga ini bernama "Safa Agro Inovasi", yang beralamat di J1 Raya Baron Gang Pattimura RT 01 RW 03 Dusun Wates Desa Baron Kecamatan Baron Kabupaten Nganjuk. Buah naga adalah buah dari beberapa jenis kaktus (Faiqoh, 2014). Komunitas petani buah naga di dusun Wates Desa Baron Kecamatan Baron Kabupaten Nganjuk telah melakukan budidaya tanaman buah naga. Tanaman buah naga yang dibudidayakan adalah buah warna merah dan daging buah warna merah.Komunitas petani buah naga ini, selain menjual hasil budidaya buah naga juga melakukan pengolahan buah naga. Tujuan kegiatan ini adalah untuk meningkatkan kualitas buah naga. Karena jika masa panen harga jual buah naga sangat rendah, yaitu $\mathrm{Rp} 4.000$,- per kg. Pengusaha olahan buah naga ini guna memenuhi kebutuhan konsumen dituntut terus untuk meningkatkan produksi dan kualitas.

Murahnya harga buah naga pada saat panen raya, memunculkan ide dikalangan anak muda yang tergabung dalam Komunitas Tani Buah Naga (Kotanaga) Kabupaten Nganjuk untuk mengolah buah naga menjadi beberapa produk olahan. Salah satunya adalah produk Stik. Namun, produksi produk Stik ini mengalami beberapa hambatan, antara lain masih rendahnya minat masyarakat untuk mengkonsumsi produk ini, produk ini hanya diproduksi pada saat musim buah naga, dan masih rendahnya peran pemerintah daerah untuk mengembangkan produk olahan buah naga ini.

Pemilik usaha stik buah naga "ENZI" ini adalah seorang ASN yang bertugas sebagai penyuluh pertanian di Desa Baron Kecamatan Baron Kabupaten Nganjuk. Pemilik dalam menjalankan usahanya dibantu oleh putranya. Pemilik usaha selain sebagai ASN, juga sebagai petani buah naga. Pada saat Tim melakukan kegiatan pengabdian kepada masyarakat dan mendatangi lokasi usaha, pada saat itu pemilik usaha menyampaikan bahwa buah naganya baru ditanam dan pada saat ini belum berbuah. Hal inilah yang menyebabkan proses produksi stik buah naga tidak dilakukan.

Berdasarkan pengamatan dan hasil observasi yang dilakukan oleh Tim, maka usaha Stik buah naga ini memiliki potensi dan peluang usaha yang masih cukup besar, karena: a) Di Kabupaten Nganjuk masih belum banyak pengusaha stik buah naga, sehingga pesaing usaha masih kecil; b) Potensi untuk memproduksi stik buah naga masih tinggi; c) Di pasaran juga masih jarang ditemukan stik buah naga; d) Dengan murahnya harga bahan baku akan menyebabkan kemudahan mendapatkan bahan baku; e) Peluang ekspor ke daerah di luar Nganjuk masih terbuka luas; f) Harga terjangkau; g) Beraneka ragam rasa. Produksi buah ini per hari masih kurang lebihnya $10 \mathrm{~kg}$ per hari dengan bahan-baku buah naga sebanyak $2 \mathrm{~kg}$ per hari. Dari sisi produksi, ini masih merupakan potensi untuk dikembangkan. Sedangkan dari sisi penjualan masih menggunakan sistem by order (pesanan). Dari sisi penjualan masih ada peluang untuk ditingkatkan dengan menggunakan sistem pemasaran yang modern, yaitu by online, vlog dan lain sebagainya.

Berdasarkan uraian di atas, dapat diidentifikasi permasalahan mitra adalah (1) Mitra belum memiliki tenaga bidang pemasaran; dan (2) Belum memiliki pencatatan/pembukuan keuangan yang sistematis dan sederhana, Tujuan dari kegiatan

Sub Tema Ekonomi, Sosial, dan Budaya 98. 
pengabdian masyarakat ini adalah membantu memberikan solusi atau pemecahan masalah kepada Mitra. Solusi yang ditawarkan kepada Mitra antara lain: 1) ) memberikan pelatihan dan pendampingan dalam perekrutan tenaga pemasaran, 2) memberikan pendampingan dan pelatihan dalam teknik pemasaran. 3) memberikan pelatihan dan pendampingan pembuatan pembukuan keuangan sederhana dengan menggunakan program excel. Metode yang digunakan dalam kegiatan pengabdian masyarakat ini adalah 1) pelatihan dan pendampingan perekrutan tenaga pemasaran dan kerjasama pemasaran dengan pihak lain, 2) pelatihan dan pendampingan pemasaran secara online (Vlog dan Youtube), dan 3) pelatihan dan pendampingan pembuatan pembukuan sederhana dengan menggunakan excel

Usaha rumahan adalah sebuah usaha mikro yang memiliki potensi usaha untuk dikembangkan (Sari \& Muttaqin, 2020). Salah satu ukuran keberhasilan usaha mikro ditinjau dari keberhasilan bidang manajemen, baik administrasi, pemasaran dan keuangan. Pelaku usaha, minimal memiliki pengetahuan tentang pengelolaan keuangan usaha. Pengelolaan keuangan usaha ini sangat diperlukan oleh pelaku usaha untuk berbagai tujuan. Salah satunya adalah untuk mendapatkan bantuan modal usaha. Pelatihan dan penyuluhan tentang pembuatan laporan keuangan laba/rugi pernah dilakukan oleh (Kurniawati et al., 2019).

Dalam kegiatan pengabdian masyarakat ini (Kurniawati et al., 2019), menggunakan kelompok sasaran kelompok usaha PKK dengan hasil sebagai berikut: 1) Kelompok Usaha PKK Kelurahan Panggung Lor telah mengetahui dan bertambah tentang wawasan ilmu pengetahuan pembukuan usahanya, dan 2) Kelompok Usaha PKK Kelurahan Panggung Lor telah mampu melakukan pembukuan usaha berupa laporan laba/rugi dalam mensukseskan usahanya. Pelatihan-pelatihan yang telah diberikan kepada para pelaku umkm dapat meningkatkan wawasan para pelaku umkm (Amin \& Marli, 2019). Keberhasilan sebuah usaha dapat ditunjukkan dengan adanya peningkatan jumlah omzet penjualan (Garside et al., 2020).

Penggunaan metode pelatihan dan pendampingan dalam melakukan kegiatan pengabdian kepada masyarakat ini dikatakan masih relevan. Hal ini tampak pada kegiatan pelatihan dan pendampingan yang dilakukan oleh Tim kepada Mitra. Walaupun metode pelatihan dan pendampingan ini dapat dikatakan sebagai sebuah metode konvensional tetapi masih efektif untuk dilakukan.

\section{METODE}

Metode yang digunakan dalam kegiatan pengabdian kepada masyarakat adalah pelatihan dan pendampingan.terhadap Mitra yang berjumlah 1 (satu) unit usaha pengolahan buah naga. Kegiatan dimulai dengan mengidentifikasi tingkat kebutuhan, proses produksi dilaksanakan, dan pengetahuan tentang pembuluan dengan cara melakukan wawancara antara tim dengan pemilik usaha.

Seteleh dilakukan wawancara, ditemukan hasil bahwa MItra masih belum membutuhkan tenaga pemasaran, Mitra masih kesulitan dalam melakukan produksi karena buah naga belum musim, Mitra belum memiliki pencatatan pembukuan. Bidang pemasaran Mitra telah melakukan melalui cara konvensional dan modern (memanfaatkan technologi informasi).

\section{HASIL DAN PEMBAHASAN}

Wawancara dilakukan untuk menggali data tentang kondisi usaha pengolahan buah naga, sebelum dilakukan pelatihan. Dari hasil wawancara ditemukan bahwa: 1) Mitra sudah ingin beralih usaha tidak lagi memproduksi stik buah naga, tetapi memproduksi minuman dan selai buah naga, hal ini disebabkan karena pengolahan buah naga menjadi stik itu membutuhkan waktu yang lama dan hasilnya tidak maksimal. 2) Pada saat pandemi covid-19, Mitra tidak melakukan proses produksi, sehingga produksi berhenti, hal ini juga disebabkan karena buah naga masih belum musim. 3) Mitra masih

Sub Tema Ekonomi, Sosial, dan Budaya 
belum membutuhkan tenaga pemasaran, karena produk stik buah naga diproduksi hanya pada saat ada pesanan. 4) Volume penjualan menurun sangat tajam pada saat masa pandemic, 5) Masih belum familiarnya masyarakat dengan makanan stik buah naga, sehingga menyebabkan jenis makanan ini belum maksimal produksinya. 6) Pada bulan Juni sampai dengan September buah naga belum panen, sehingga Mitra tidak melakukan proses produksi pembuatan stik buah naga. 7) Mitra masih belum memerlukan pencatatan pembukuan, karena usaha pengolahan buah naga ini masih belum konsisten, 8) Promosi sudah dilakukan secara konvensional dengan menitipkan produk pada warung-warung terdekat dan secara getok tular dari teman ke teman, dari keluarga ke keluarga yang lain. 9) promosi juga telah dilakukan dengan menggunakan kemajuan teknologi informasi, yaitu melalui media social Facebook, Tweeter dan Instagram. 10) Promosi juga sudah dilakukan dengan menggandeng pihak ketiga yaitu Pemerintah Kabupaten Nganjuk, tetapi ini belum optimal hasilnya. 11) Promosi belum dilakukan dengan melakukan kerjasama dengan sekolah-sekolah yang ada di kecamatan Baron Kabupaten Nganjuk. 12) Mitra masih kekurangan modal, baik dalam bentuk uang, mesin dan tenaga kerja.

Selain melakukan wawancara dengan pelaku/pemilik usaha, Tim juga melakukan wawancara dengan masyarakat di lingkungan pengusaha, yaitu di Desa Baron Kecamatan Baron Kabupaten Nganjuk. Hasil wawancara dengan masyarakat di sekitar lokasi usaha, sebagai berikut: 1) Sebagian besar masyarakat sekitar lokasi usaha stik buah naga merk "ENZI" belum begitu mengenal dengan stik buah naga, bahkan bentuk dan rasanya juga belum begitu dikenal. 2) masyarakat hanya mengenal pemilik usaha sebagai petugas penyuluh pertanian dibandingkan dengan sebagai pengusaha olahan stik buah naga. 3) Ada yang pernah membeli stik buah naga merk "ENZI" mereka memberikan komentar bahwa harga stik buah naga merk "ENZI" mahal dibandingkan dengan merk yang lain.
Dari hasil wawancara dengan masyarakat di Desa Baron Kecamatan Baron Kabupaten Nganjuk, menunjukkan bahwa pengusaha belum melakukan promosi produknya secara optimal di desanya sendiri, sehingga produk tersebut belum dikenal oleh masyarakat sekitar. Selain itu, pengusaha juga belum melakukan kerjasama dengan sekolah-sekolah kejuruan yang memiliki konsentrasi pemasaran agar dapat membantu pengusaha dalam memasarkan produknya.

Tim telah menawarkan beberapa solusi kepada Mitra untuk membantu memecahkan masalah Mitra, yaitu: Tim memberikan pelatihan dan pendampingan dalam bentuk tutorial, yaitu video tutorial tentang 1) cara merekrut tenaga pemasaran, 2) cara membuat pencatatan/pembukuan sederhana dan sistematis dengan menggunakan excel, dan 3) cara melakukan pemasaran secara online melalui media social (youtube dan video blogger). Sedangkan untuk kerjasama dengan sekolah-sekolah belum bisa dilaksanakan karena terhambat oleh aturan pemerintah tentang penyelenggaraaan pendidikan di sekolah-sekolah yang belum diperbolehkan untuk melakukan tatap muka. Video tutorial dan video blogger ini dapat diunduh pada link https://www.youtube.com/channel/UCC2D_tiNC Y9 NnJx-aDRIkQ. Hasil wawancara tampak pada Gambar 1 berikut ini:

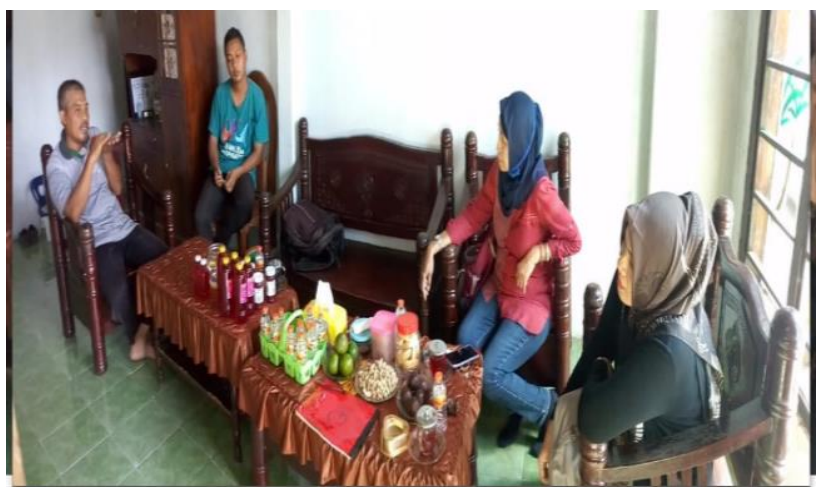

Gambar 1. Wawancara Tim dengan pemilik usaha

Gambar 1 menunjukkan bahwa Tim sebelum melakukan kegiatan pelatihan dan pendampingan melakukan wawancara dengan pemilik usaha olahn buah naga Stik buah naga

Sub Tema Ekonomi, Sosial, dan Budaya $\quad 98^{\circ}$ 
"ENZI" di lokasi usaha Desa Baron Kecamatan Baron Kabupaten Nganjuk. Produk yang diperlihatkan kepada tim berupa minuman dari buah naga dan selai buah naga, sedangkan stik buah naga pada saat itu tidak produksi, dengan alasan buah naganya baru menanam dan belum berbuah.

Tim juga membantu promosi produk yang telah dihasilkan oleh MItra, yaitu minuman sari buah naga dan selai buah naga melalui link youtube tim, seperti yang tampak pada gambar 2 berikut:

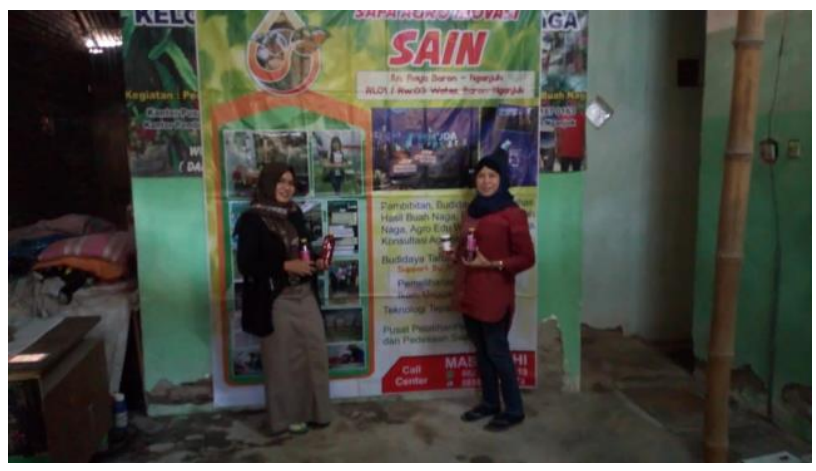

Gambar 2. Gambar Tim saat mempromosikan produk

Hambatan yang dihadapi oleh Mitra dalam mengembangkan usaha olah stik buah naga ini akan dapat teratasi, jika ada bantuan dan kerjasama dari Pemerintah Kabupaten Nganjuk dalam penyediaan bahan baku buah naga yang dibutuhkan oleh Mitra. Setelah Mitra mempelajari tutorial yang diberikan oleh Tim, ada beberapa kendala yang dihadapi oleh Mitra, antara lain: 1) Di bidang keuangan, yaitu Mitra belum memiliki tenaga bidang keuangan, sehingga tutorial tersebut hanya sebagai wacana/bahan untuk membuat pembukuan setelah adanya tenaga keuangan. 2) Di bidang pemasaran, hambatan yang dialami oleh Mitra adalah untuk membuat fiture video vlog yang baik dikarenakan akses jaringan yang terkadang mengalami hambatan. Selain itu, kecanggihan informasi melalui internet sangat dibutuhkan oleh pebisnis atau pelaku usaha dalam mengembangkan usahanya (Werdani et al., 2020).
Dari kegiatan PKM ini, belum dapat dilihat hasil dari usaha, karena pada saat kegiatan PKM dilakukan Mitra tidak melakukan produksi dan juga dalam kondisi pandemic Covid-19, sehingga ada beberapa kendala untuk melakukan kegiatan PKM sesuai dengan yang diusulkan. Jika, pelatihan dapat dilakukan secara efektif, maka akan bermanfaat bagi Mitra. Pemberdayaan yang dilakukan akan membawa dampak pada Mitra, yaitu dapat berupa peningkatan omzet penjualan, penambahan wawasan dan pengembangan jaringan usaha (Masnita \& Triyowati, 2020). Bantuan modal kerja diperlukan oleh pelaku usaha. Bantuan modal kerja ini dapat melalui pemerintah ataupun swasta ( et al., 2019). Penggunaan sistem informasi dalam pembuatan laporan keuangan akan dapat dilakukan dengan cepat dan laporan keuangan akan lebih akurat hasilnya (Kristanto, 2020).

Dampak kegiatan PkM ini bagi Mitra sasaran adalah positif, karena walaupun kegiatan ini dilakukan pada saat pandemic covid-19, Mitra sangat antusias untuk mengembangkan usaha dengan mengikuti saran dari TIM. Dampaknya antara lain: 1) Mitra segera akan melaksanakan MOU dengan Sekolah-sekolah yang memiliki jurusan pemasaran. 2) Mitra akan segera merekrut tenaga pemasaran jika pandemic covid-19 sudah tidak ada. 3) Mitra akan merekrut tenaga pembukuan dan mengaplikasikan tutorial yang sudah diberikan oleh Tim.

\section{SIMPULAN}

1. Setelah dilakukan pelatihan dan pendampingan di bidang pemasaran, disepakati antara Tim dan MItra bahwa Mitra akan segera melakukan rekrutmen tenaga pemasaran setelah produksi berlangsung kembali.

2. Setelah dilakukan pelatihan dan pendampingan dalam penyusunan pembukuan keuangan, Mitra sepakat untuk segera melakukan rekrutmen tenaga bidang keuangan dan selama belum ada tenaga bidang keuangan, bidang ini dilaksanakan oleh putranya pemilik usaha.

Sub Tema Ekonomi, Sosial, dan Budaya $\quad 988$ 
3. Setelah dilakukan pemahaman, inspirasi dan pendampingan, muncul kreativitas baru untuk membuat produk lain selain stik buah naga, yang berupa minuman dan selai buah naga.

\section{UCAPAN TERIMA KASIH}

Tim menyampaikan ucapan terima kasih kepada Rektor, Wakil Rektor II dan Kepala LPPM Universitas Wijaya Putra Surabaya, yang telah mendanai kegiatan Pengabdian Kepada Masyarakat ini.

\section{REFERENSI}

Amin, A., \& Marli. (2019). Pkm Pengusaha Tahu Sayur Dan Keripik Tahu Karangrejo Selatan Desa Purworejo Kecamatan Donomulyo Kabupaten Malang. J-Abdimas, 6(2), 101108. http://jabdimas.polinema.ac.id/index.php/abdimas/art icle/view/70

Anonim. (2019). Kabupaten Nganjuk dalam Angka 2018. In BPS Kabupaten Nganjuk. https://nganjukkab.bps.go.id/publication/2018/ 08/16/01a1c46cdf57380bf65f4f16/kabupatennganjuk-dalam-angka-2018.html

Faiqoh, E. N. (2014). Pengaruh Konsentrasi Dan Lama Perendaman Dalam Cacl2 (Kalsium Klorida) Terhadap Kualitas Dan Kuantitas Buah Naga Super Merah (Hylocereus costaricensis). Jurnal Sains Dan Teknologi, 9(September), 1-10. http://etheses.uinmalang.ac.id/445/12/10620070 Ringkasan.pdf

Garside, A. K., Baroto, T., \& Gunarimba Waibo, O. R. (2020). Penguatan Aspek Produksi dan Pemasaran pada Usaha Keripik Singkong Mix Sayur. JPPM (Jurnal Pengabdian Dan Pemberdayaan Masyarakat), 4(1), 61. https://doi.org/10.30595/jppm.v0i0.4614

Kristanto, S. B. (2020). Asistensi akuntansi keuangan desa marga mulya. SULUH: Jurnal Abdimas, 2(2), 21-32. http://journal.univpancasila.ac.id/index.php/S ULUH/article/view/1548/986
Kurniawati, E., Santoso, A., Widowati, S. Y., \& İ, F. E. N. B. İ. L. G. İ. S. İ. Ö. Ğ. R. E. T. İ. M. (2019). Penyuluhan Guna Penunjang Kesuksesan Usaha Ukm Berbasis Pembukuan Usaha Laporan Laba/Rugi. J-Abdimas, 6(2), 88-94. $\mathrm{http}: / / \mathrm{j}-$ abdimas.polinema.ac.id/index.php/abdimas/art icle/view/68

Masnita, Y., \& Triyowati, H. (2020). Peningkatan Daya Saing Usaha Mikro ( UMi ) Melalui Keuangan Inklusi. DINAMISIA, 4(2), 255261.

https://journal.unilak.ac.id/index.php/dinamisi a/article/view/3964/2197

Masnita, Y., Triyowati, H., \& Khomsiyah. (2019). Application of Financial Inclusions in Indonesia: a Study on Vulnerable Group. Eurasian Journal of Economics and Finance, 7(3), 22-33. https://doi.org/10.15604/ejef.2019.07.03.003

Sari, D. S., \& Muttaqin, Z. (2020). Potensi Usaha Rumahan di Desa Jatisari Kabupaten Sumedang. Jurnal Pengabdian Kepada Masyarakat, 4(1), 1-5. http://researchreport.umm.ac.id/index.php/researchreport/article/view/834/1047

Werdani, R. E., Kurniawati, N. I., Sukoco, J. B., Windriya, A., \& Iskandar, D. (2020). Pelatihan Pemasaran Produk Homemade Melalui Sosial Media. JPPM (Jurnal Pengabdian Dan Pemberdayaan Masyarakat), 4(1), 1. https://doi.org/10.30595/jppm.v4i1.4655 